\title{
Water Quality in Marmara Sea
}

\section{Esin BOZKURT KOPUZ ${ }^{*}$, Gökberk KARA ${ }^{2}$}

ABSTRACT: The purpose of the study is to determine the water quality for the continuity of the aquatic life' diversity and the health of the citizens and tourists swimming in the Kucuksu, Fenerbahce and Suadiye beaches. Between 5 June 2019 and 29 August 2019, water temperature, pH, dissolved oxygen and salinity were measured weekly onsite and seawater samples were collected to analyze heavy metal concentrations ( $\mathrm{Ba}, \mathrm{Cr}, \mathrm{Mn}, \mathrm{Ni}, \mathrm{Cu}, \mathrm{Zn}, \mathrm{Pb}, \mathrm{Cd}$ and $\mathrm{Se}$ ) via ICP-OES. Results showed that values are under the limits and there is no harm to human health and aquatic life. The measurements were compared with the literature data of beaches in the Mediterranean and of the same beaches in the previous studies.

Keywords: Marmara Sea, sea water quality, beaches, recreation

${ }^{1}$ Esin BOZKURT KOPUZ (Orcid ID: 0000-0002-9950-7279), Marmara University, Faculty of Engineering, Civil Engineering Department, Istanbul, Turkey

2 Gökberk KARA (Orcid ID: 0000-0001-9204-3486), Marmara University, Faculty of Engineering, Department of Environmental Sciences Master Student, Istanbul, Turkey

*Corresponding Author: Esin BOZKURT KOPUZ, e-mail: esin.bozkurt@marmara.edu.tr 


\section{INTRODUCTION}

As in the study of the Baltic Sea (Storie et al., 2020), healthy marine ecosystems provide many benefits to the society, but the hazardous substances can be in the seafood due to the human impact on the environment. So accumulated heavy metals in marine organisms such as fishes and bivalves pose toxicity on human health via the food chain (Yuan et al., 2020). Aluminum can cause Alzheimer's disease, lead Plumbism, copper at levels above $100 \mathrm{mg} \mathrm{L}^{-1}$ vomiting and liver damage, selenium dental caries, manganese black stain, cadmium accumulating in kidney and liver. Barium can stimulate the heart muscles and affect the gastrointestinal tract and central nervous system (Alley, 2007).

$\mathrm{pH}$ naturally decreases at night and increases daytime because of the aquatic organism's respiratory and phytoplankton's photosynthetic activities. But highly acidic or alkaline seawater can directly damage the skin, gills and pores in fish (Ölmez and Sarac, 2009).

While producing dissolved oxygen by photosynthesis, it is consumed by breathing or respiration by marine organisms. Depletion of dissolved oxygen can affect movement and reproduction of marine organisms, storage of organic matter in the sediments, nitrate remove, production of greenhouse gases such as nitrous oxide, and the release of phosphorus and iron from sediments (Mahaffey et al., 2020).

The sea water salinity affects the morphology, vital activities and distribution of the organisms. While some bacteria and algae tolerate low salinity differences (homeosmotic), most primitive plants and animals can withstand large salinity differences (eurihalin) (Kocataş, 2005). For example, the minimum salinity required for bream fish is $\% 5$ and the highest is $\%_{0} 40$, and the temperature range they can survive is $3-34{ }^{\circ} \mathrm{C}$ (Chervinski and Chanin, 1985).

In this study, temperature, $\mathrm{pH}$, dissolved oxygen and salinity measured onsite and concentrations of aluminum ( $\mathrm{Al})$, barium $(\mathrm{Ba})$, chromium $(\mathrm{Cr})$, manganese $(\mathrm{Mn})$, iron $(\mathrm{Fe})$, cobalt $(\mathrm{Co})$, nickel $(\mathrm{Ni})$, copper $(\mathrm{Cu})$, zinc $(\mathrm{Zn})$, lead $(\mathrm{Pb})$, cadmium $(\mathrm{Cd})$ and selenium $(\mathrm{Se})$ in water samples collected from Kucuksu, Fenerbahce and Suadiye beaches between 5 June 2019 and 29 August 2019 were investigated to determine the effects on public health.

\section{MATERIALS AND METHODS}

\section{Experimental Procedure}

100 ml-polyethylene bottles, which were soaked in a mixture of nitric acid and deionized water for 24 hours, rinsed three times with deionized water and dried in the oven, were used for sample collection. The bottle at the end of the telescopic rod (Batley, 1989) was rinsed three times with water $50 \mathrm{~cm}$ below the water surface and filled with sea water.

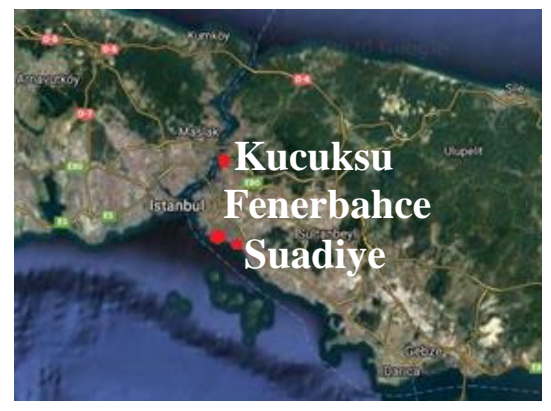

Figure.1. Kucuksu, Fenerbahce and Suadiye beaches (Anonymous, 2020).

Sea water temperature, dissolved oxygen and $\mathrm{pH}$ were measured with multiparameter (YSI) device. Sea water collected from three beaches (Figure 1) was filtered with a $0.45 \mu \mathrm{m}$ sieve syringe filter (Sartorius) and sterile syringe in the laboratory of Marmara University. In order to have a pH below 2, 
$2 \%$ nitric acid $\left(\mathrm{HNO}_{3}\right)$ was added and placed in a $4{ }^{\circ} \mathrm{C}$ refrigerator. All prepared samples were analyzed with ICP-OES for heavy metals.

\section{RESULTS AND DISCUSSION}

pH values measured between June 5, 2019 and August 29, 2019 were within the threshold ranges for Turkey (General Quality Criteria of Sea Water in Turkey, 2004; Turkey Recreational Standards, 2006) (6-9) and EPA (U.S. EPA, 1986) (5-9 for human health, and 6.5-8.5 for aquatic life) are given in Figure 2a. Figure $2 \mathrm{~b}$ shows dissolved oxygen in the threshold ranges for Turkey.

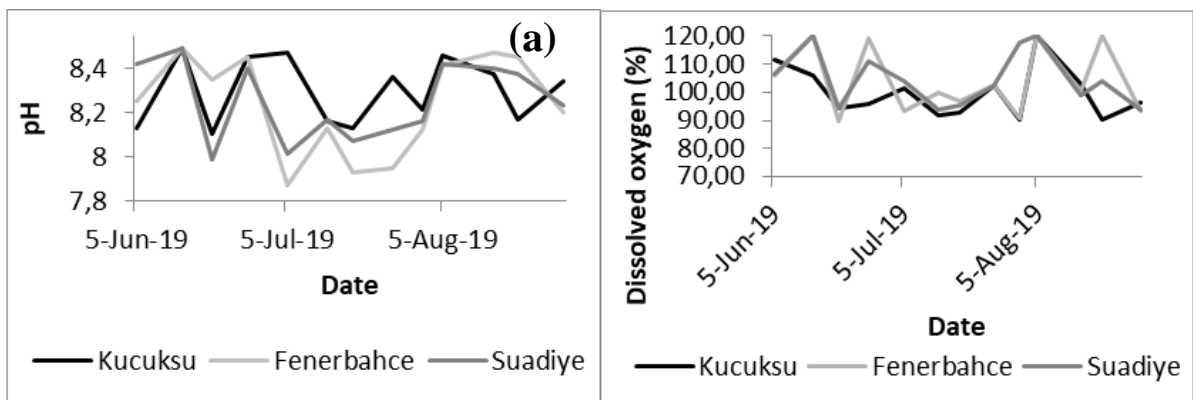

(b)

Figure.2 (a) $\mathrm{pH}$ and (b) dissolved oxygen.
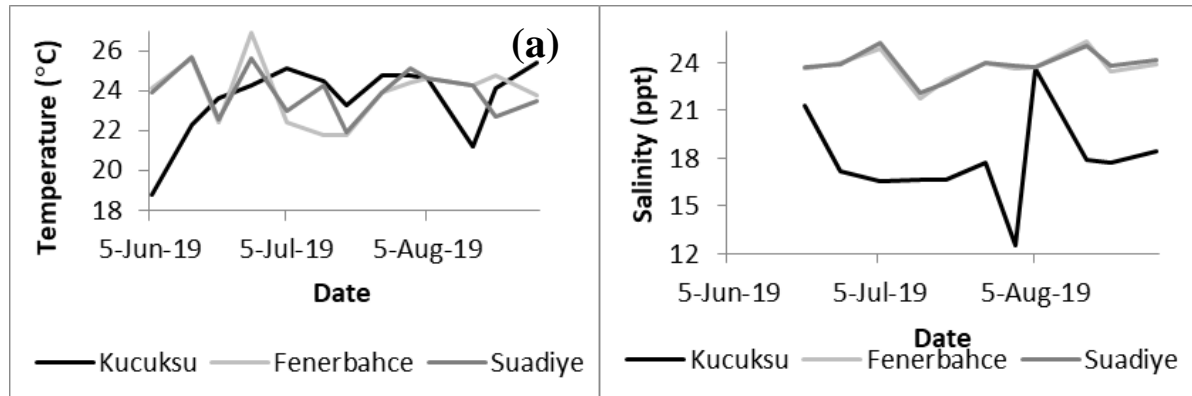

(b)

Figure.3. (a) Sea water temperatures and (b) salinity.

Sea water temperatures (Figure 3a), $\mathrm{pH}$, and dissolved oxygen range from the three sites between 18.8 and $26.9{ }^{\circ} \mathrm{C}$, between 7.87 and 8.49 , and between 90 and $120 \%$ respectively. The weekly salinity was in the range of 12.54 to $25.3 \%$ so the values did not exceed the U.S. EPA human health standard for the consumption of water and organism (Figure 3b). In addition, sea water temperatures and salinity were very similar in Fenerbahce and Suadiye beaches. In Fenerbahce, water temperatures ranged from 21.8 to $26.9{ }^{\circ} \mathrm{C}$, with a higher range of 18.8 to $25.4{ }^{\circ} \mathrm{C}$ in Kucuksu, with a lower range of 21.9 to 25.7 ${ }^{\circ} \mathrm{C}$ in Suadiye. The weekly salinity from the Fenerbahce and Suadiye beaches were from 22 to $25 \%$ but from Kucuksu it was in the range of 13 to $24 \%$.

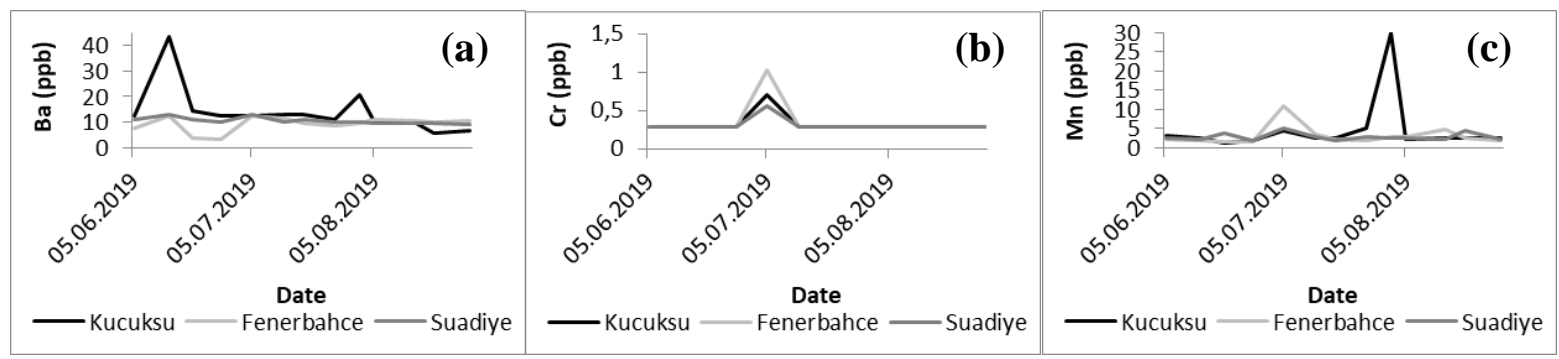

Figure.4. (a) $\mathrm{Ba}$, (b) $\mathrm{Cr}$, and (c) $\mathrm{Mn}$ (ppb). 

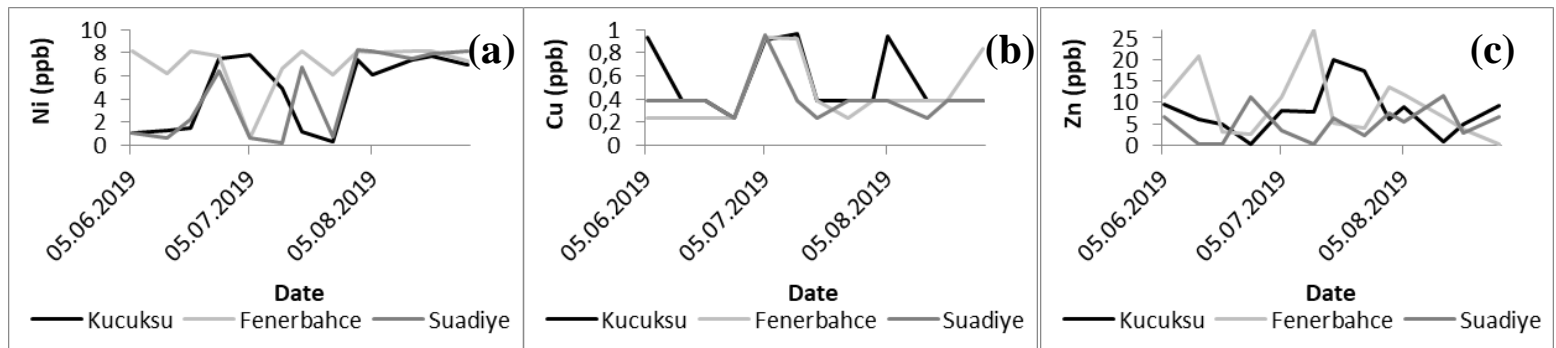

Figure.5. (a) $\mathrm{Ni}$, (b) $\mathrm{Cu}$, and (c) $\mathrm{Zn}(\mathrm{ppb})$.
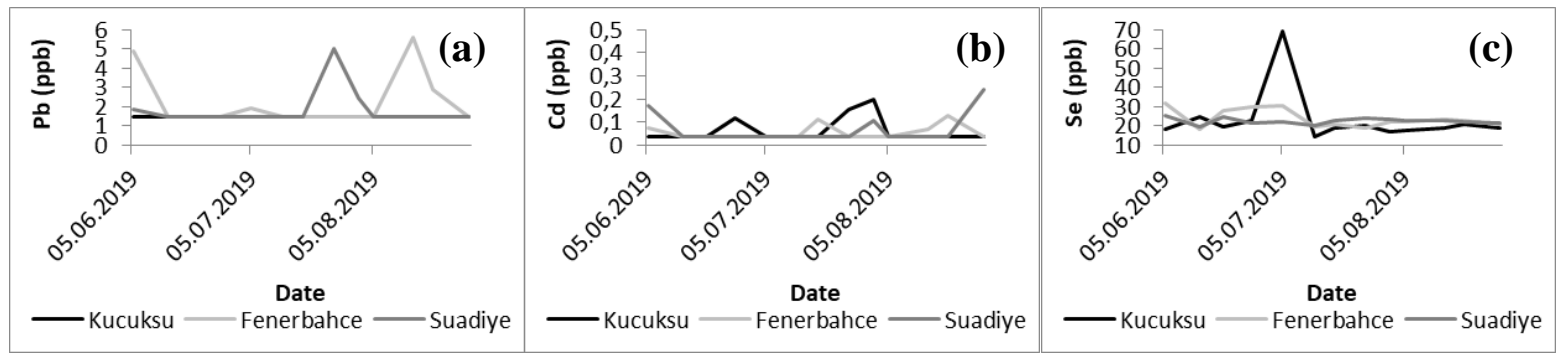

Figure.6. (a) $\mathrm{Pb}$, (b) $\mathrm{Cd}$, and (c) $\mathrm{Se}(\mathrm{ppb})$.

$\mathrm{Ba}, \mathrm{Cr}, \mathrm{Mn}, \mathrm{Ni}, \mathrm{Cu}, \mathrm{Zn}, \mathrm{Pb}, \mathrm{Cd}$ and $\mathrm{Se}$ varies among different sampling sites from 3.4 to $43.3 \mathrm{ppb}$, from 0.3 to $1.0 \mathrm{ppb}$, from 1.4 to $28.8 \mathrm{ppb}$, from 0.3 to $8.2 \mathrm{ppb}$, from 0.2 to $1.0 \mathrm{ppb}$, from 0.2 to $26.7 \mathrm{ppb}$, from 1.4 to $5.6 \mathrm{ppb}$, from 0.04 to $0.24 \mathrm{ppb}$, and from 14.7 to $69.3 \mathrm{ppb}$ respectively (Figure 4, 5, and 6). Comparison of results showed that none of the metal concentrations ( $\mathrm{Ba}, \mathrm{Cr}, \mathrm{Mn}, \mathrm{Ni}, \mathrm{Cu}, \mathrm{Zn}, \mathrm{Pb}, \mathrm{Cd}$ and Se) exceeded the Turkish recreational and general sea quality standards or EPA human health and aquatic life standards (Table 1).

Table 1. The Turkish recreational (Turkey Recreational Standards, 2006), general sea quality standards (General Quality Criteria of Sea Water in Turkey, 2004), and EPA human health and aquatic life standards (U.S. EPA, 1986).

\begin{tabular}{|c|c|c|c|c|c|c|}
\hline Parameter & $\begin{array}{c}\text { Turkey } \\
\text { Recreational } \\
\text { Standards }\end{array}$ & $\begin{array}{l}\text { General } \\
\text { Quality } \\
\text { Criteria Of } \\
\text { Sea Water } \\
\text { in Turkey }\end{array}$ & $\begin{array}{c}\text { U.S. EPA } \\
\text { Human } \\
\text { Health } \\
\text { standard for } \\
\text { the } \\
\text { consumption } \\
\text { of Water + } \\
\text { Organism }\end{array}$ & $\begin{array}{c}\text { U.S. EPA } \\
\text { Human } \\
\text { Health } \\
\text { standard for } \\
\text { the } \\
\text { consumption } \\
\text { of Organism } \\
\text { Only }\end{array}$ & $\begin{array}{l}\text { U.S. EPA } \\
\text { Aquatic } \\
\text { Life } \\
\text { Criteria } \\
\text { for } \\
\text { saltwater } \\
\text { (acute) }\end{array}$ & $\begin{array}{c}\text { U.S. EPA } \\
\text { Aquatic } \\
\text { Life } \\
\text { Criteria } \\
\text { for } \\
\text { saltwater } \\
\text { (chronic) }\end{array}$ \\
\hline $\mathrm{Cu}\left(\mu \mathrm{g} \mathrm{L}^{-1}\right)$ & - & 10 & 1300 & - & 4.8 & 3.1 \\
\hline$C d\left(\mu g L^{-1}\right)$ & 10 & 10 & - & - & 33 & 7.9 \\
\hline $\operatorname{Cr}\left(\mu g \mathrm{~L}^{-1}\right)$ & 100 & 100 & - & - & 1100 & 50 \\
\hline$P b\left(\mu g L^{-1}\right)$ & 100 & 100 & - & - & 140 & 5.6 \\
\hline $\mathbf{N i}\left(\mu \mathrm{g} \mathrm{L}^{-1}\right)$ & - & 100 & 610 & 4600 & 74 & 8.2 \\
\hline $\operatorname{Zn}\left(\mu \mathrm{g} \mathrm{L}^{-1}\right)$ & - & 100 & - & - & 90 & 81 \\
\hline $\operatorname{Se}\left(\mu \mathrm{g} \mathrm{L}^{-1}\right)$ & - & - & 170 & 4200 & 290 & 71 \\
\hline $\mathrm{Ba}\left(\mu \mathrm{g} \mathrm{L}^{-1}\right)$ & - & - & 1000 & - & - & - \\
\hline $\operatorname{Mn}\left(\mu \mathrm{g} \mathrm{L}^{-1}\right)$ & - & - & 50 & 100 & - & - \\
\hline $\operatorname{Zn}\left(\mu \mathrm{g} \mathrm{L}^{-1}\right)$ & - & - & 7400 & 26000 & - & - \\
\hline pH & $6.0-9.0$ & $6.0-9.0$ & $5.0-9.0$ & - & - & $6.5-8.5$ \\
\hline Dissolved oxygen (\%) & $80-120$ & $90<$ & - & & - & - \\
\hline Salinity $\left(\mu \mathrm{g} \mathrm{L}^{-1}\right)$ & - & - & 250000 & - & - & - \\
\hline
\end{tabular}

Strength of association for Pearson correlation was investigated according to the ranges in the study of Bozkurt Kopuz et al., 2017. Temperature (0.71), pH (0.77), dissolved oxygen (0.59), and salinity (0.98) had strong positive correlations between Fenerbahce and Suadiye. Therefore, when one of these values increased for Fenerbahce, same value increased for Suadiye. For Kucuksu and Fenerbahce and 
for Kucuksu and Suadiye, temperature had weak negative correlations and salinity had also weak positive correlations.

Dissolved oxygen and $\mathrm{pH}$ correlation was 0.50 for Kucuksu, 0.63 for Fenerbahce, and 0.55 for Suadiye and these correlations were strong for all beaches. For Kucuksu, dissolved oxygen and salinity had strong positive correlation (0.62). There was a positive correlation between temperature and $\mathrm{pH}$ and between temperature and dissolved oxygen for Fenerbahce and for Suadiye in the range from 0.61 to 0.71 .

\section{Comparisons with the Literature}

In the same beaches, the $\mathrm{pH}$, and Ni values between Feburary 9 and May 4, 2009 and temperature values on the may 2009 in the previous study were similar with the values measured in this study but only $\mathrm{Pb}$ values were a little higher than values in this study. (Bozkurt et al., 2014). The $\mathrm{pH}$ values measured from 19 October 2016 to 26 March 2017 and the $\mathrm{pH}$, dissolved oxygen, $\mathrm{Cr}, \mathrm{Ni}, \mathrm{Zn}, \mathrm{Pb}$ values from 18 November 2018 to 31 January 2019 and temperature values on the october 2016 and november 2018 were similar with the values measured in this study (Bozkurt Kopuz et al., 2019).

The highest value in Gulluk Lagoon, Turkey between June 2011 and May 2012 was $29.76{ }^{\circ} \mathrm{C}$ in July in Özdemir and Alparslan's study (Özdemir and Alparslan, 2013) and was higher than the values we measured in the Marmara Sea. The sea water temperature of the Karavasta lagoon in Albania in the spring of 2013 between $19{ }^{\circ} \mathrm{C}$ and $23.5^{\circ} \mathrm{C}$ (Koto et al., 2014), the highest sea water temperatures of the Butrinti lagoon in Albania between May 2010 and January 2011 from $26^{\circ} \mathrm{C}$ to $27.3{ }^{\circ} \mathrm{C}$ in August (Topi et al., 2013), and June-July mean sea water temperatures in the range of $24.6^{\circ} \mathrm{C}$ and $26.3{ }^{\circ} \mathrm{C}$ in the BagesSigean and Canet-St Nazaire lagoons (France) in 2009 (Vouvé, 2014) were close to our measurements in the Marmara Sea. In the summer of 2014 , minimum $28.2{ }^{\circ} \mathrm{C}$ and maximum $33.6{ }^{\circ} \mathrm{C}$ sea water temperature values for the Akyatan lagoon in Turkey (Demir et al., 2014) were higher than our values.

Alkaline $\mathrm{pH}$ values in the lagoons in Albania, France, and Turkey (Topi et al, 2013, Demir et al., 2014, Koto et al., 2014, Vouvé et al., 2014) except acidic values between 6.03 and 6.92 in Gulluk lagoon (Özdemir and Alparslan, 2013) were similar to our pH measurements.

The maximum salinity of the Gulluk Lagoon (39.98 \%o), the hyper-saline Akyatan lagoon (119.6 \%o) in Turkey, the Karavasta lagoon (34.6\%o), the Butrinti lagoon (28.8\%o) in Albania, the Bages-Sigean (40.1\%o) and Canet-St Nazaire (35.6) lagoons in France were higher than our maximum measurement $(25.3 \%)$.

Averages of $\mathrm{Ba}, \mathrm{Cr}, \mathrm{Mn}, \mathrm{Ni}, \mathrm{Cu}, \mathrm{Zn}, \mathrm{Pb}, \mathrm{Cd}$ and Se were 5.21, 11.36, 0.32, 3.64, 5.41, 0.46, 7.42, $1.82,0.06$ and $23.24 \mu \mathrm{g} \mathrm{L}^{-1}$, respectively, and compared with other cities around the world are generally lower. When our study was compared with studies in literature, Iskenderun, Turkey $\left(363.66 \mu \mathrm{g} \mathrm{L}^{-1}\right)$ (Goycincik et al., 2018) had the largest overall $\mathrm{Cu}$ mean concentration, followed by Karavasta, Albania (25.52 $\left.\mu \mathrm{g} \mathrm{L}^{-1}\right)$, Butrinti, Albania $\left(20.21 \mu \mathrm{g} \mathrm{L}^{-1}\right)$, Manzala, Egypt $\left(16.17 \mu \mathrm{g} \mathrm{L}^{-1}\right)$, Bages-Sigean, France $\left(1.45 \mu \mathrm{g} \mathrm{L}^{-1}\right)$, and our study $\left(0.46 \mu \mathrm{g} \mathrm{L}^{-1}\right)$ respectively. The mean $\mathrm{Pb}$ concentration for our study was determined to be smaller than the mean $\mathrm{Pb}$ concentration for Manzala, Egypt, but not from the mean concentrations of either Karavasta or Butrinti, Albania. The largest to the smallest mean $\mathrm{Cd}$ concentrations were $2.45 \mu \mathrm{g} \mathrm{L}^{-1}$ (for Manzala, Egypt), $0.18 \mu \mathrm{g} \mathrm{L}^{-1}$ (for Bages-Sigean, France), $0.08 \mu \mathrm{g}$ $\mathrm{L}^{-1}$ (for Butrinti, Albania,) $0.06 \mu \mathrm{g} \mathrm{L}^{-1}$ (for our study, Turkey), and $0.03 \mu \mathrm{g} \mathrm{L}^{-1}$ (for Karavasta, Albania) respectively. The mean $\mathrm{Cr}$ concentration $\left(0.32 \mu \mathrm{g} \mathrm{L}^{-1}\right)$ for our study was lower than the values for Butrinti, Albania (18.10 $\left.\mu \mathrm{g} \mathrm{L}^{-1}\right)$, for Karavasta, Albania $\left(22.24 \mu \mathrm{g} \mathrm{L}^{-1}\right)$, and for Iskenderun, Turkey $\left(242.58 \mu \mathrm{g} \mathrm{L}^{-1}\right)$. The mean concentrations of $\mathrm{Ni}\left(94.35 \mu \mathrm{g} \mathrm{L}^{-1}\right)$, and $\mathrm{Se}\left(274.60 \mu \mathrm{g} \mathrm{L}^{-1}\right)$ for Iskenderun, 
Turkey and the mean concentrations of Mn $\left(177.17 \mu \mathrm{g} \mathrm{L}^{-1}\right)$ and $\mathrm{Zn}\left(278.96 \mu \mathrm{g} \mathrm{L}^{-1}\right)$ for Manzala, Egypt were higher than values for our study.

\section{CONCLUSION}

These findings indicate that there is no significant threat to human health and aquatic life from water temperature, $\mathrm{pH}$, dissolved oxygen, salinity, and heavy metals ( $\mathrm{Ba}, \mathrm{Cr}, \mathrm{Mn}, \mathrm{Ni}, \mathrm{Cu}, \mathrm{Zn}, \mathrm{Pb}, \mathrm{Cd}$ and Se) in sea water in Kucuksu, Fenerbahce, and Suadiye beaches. Water temperature and salinity were similar in Fenerbahce, and Suadiye beaches. Because of strong positive correlations between Fenerbahce and Suadiye, if one of $\mathrm{pH}$, dissolved oxygen, or salinity decreases for Suadiye, same parameter decreases for Fenerbahce too. Similarly, between dissolved oxygen and $\mathrm{pH}$, between dissolved oxygen and temperature, and between $\mathrm{pH}$ and temperature had strong positive correlation. Measured parameters in the same beaches were similar with previous studies. While the maximum sea water temperatures for the Gulluk lagoon and Akyatan lagoon in Turkey were higher than the values we measured in the Marmara Sea, the maximum sea water temperatures for the Karavasta lagoon in Albania, for the Butrinti lagoon in Albania, and for the Bages-Sigean and Canet-St Nazaire lagoons in France were close to our measurements in the Marmara Sea. While $\mathrm{pH}$ values for the Karavasta Lagoon and Butrinti lagoon in Albania, Bages-Sigean and Canet-St Nazaire lagoons in France, Akyatan Lagoon in Turkey were alkaline similar to our $\mathrm{pH}$ measurements, the values in Gulluk lagoon were acidic. The maximum salinity of the Gulluk Lagoon and the Akyatan lagoon in Turkey, the Karavasta lagoon and the Butrinti lagoon in Albania, the Bages-Sigean and Canet-St Nazaire lagoons in France were higher than our maximum salinity value. Results not only point out a representative picture of heavy metals in sea water from three beaches at the national level but also provide valuable additional information that can be used to support assessment of potentially toxic effects on human health and aquatic life.

The concentrations of $\mathrm{Cu}$ (for Butrinti and Karavasta, Albania, for Iskenderun, Turkey, for Manzala, Egypt and for Bages-Sigean, France), Cr (for Butrinti and Karavasta, Albania and for Iskenderun, Turkey), $\mathrm{Ni}$, Se (for Iskenderun, Turkey), $\mathrm{Mn}, \mathrm{Zn}, \mathrm{Pb}$ (for Manzala, Egypt) and Cd (for Manzala, Egypt, for Bages-Sigean, France and for Butrinti, Albania) were lower than the values for our study except concentrations of $\mathrm{Pb}$ for Butrinti and Karavasta, Albania and Cd for Karavasta, Albania.

Ensuring water quality in these beaches is possible by taking measures for bilge and ballast waters of ships and for discharging industrial and domestic wastewater into the sea with treatment. In addition to the parameters we measured in this study, it will be useful in the beaches to measure suspended solids, crude oil and derivatives, radioactivity and phenols in subsequent studies.

\section{ACKNOWLEDGEMENTS}

This work was supported by Research Fund of the Marmara University. Project Number: FEN-A110718-0394.

\section{REFERENCES}

Alley ER, 2007. Water Quality Control Handbook. McGraw-Hill Publications No: 2, pp. 3.10-3.15, New York-USA.

Anonymous, 2020. Google Map.

https://www.google.com.tr/maps/@40.9579878,29.1026872,93861m/data=!3m1!1e3. (Date of access: 15 June 2020).

Batley GE, 1989. Trace Element Speciation Analytical Methods and Problems. CRC Publications pp. 3, Florida, USA. 
Bozkurt E, Eliri Ö, Kesiktas M, 2014. Analysis of Heavy Metals in Seawater Samples Collected from Beaches of Asian Side of Istanbul. Journal of Recreation and Tourism Research, 1 (1): 39-47.

Bozkurt Kopuz E, Pursa A, Y1lmaz B, Özdemir E, Özturk D, 2017. Current Trends in Science and Landscape Management. St. Kliment Ohridski University Publications No: 33, pp. 417, SofiaBulgaria.

Bozkurt Kopuz E, Kara G, Dincer B, Gurtug Y, 2019. Water Quality in Istanbul, Marmara Sea, Journal of The Indian Chemical Society, 96 (9): 1189-1193.

Chervinski J, Chanin Y, 1985. Gilthead Sea Bream (Sparus Aurata L.) A Candidate For Culture İn Ponds- Laboratory Experiments. Bamidgeh 37 (2): 42.

Demir Yetiş A, Selek Z, Seckin G, Davutluoglu OI, 2014. Water Quality of Mediterranean Coastal Plains: Conservation Implications from the Akyatan Lagoon, Turkey. Environmental Monitoring and Assessment, 186 (11): 7631-7642.

General Quality Criteria of Sea Water in Turkey, 2004. in Turkish Water Pollution Control Regulation, State of Turkey, 2004, Annexes, Table 4.

Göycincik S, Danahaliloğlu H, Karayiğit HB, 2018. İskenderun Körfezi Deniz Suyunun Eser Element Düzeylerinin Araştırılması. Karadeniz Fen Bilimleri Dergisi, 8 (2): 39-48.

Kocataş A, 2005. Oseanoloji. Ege Üniversitesi Publications No: 60, pp. 255-288, Izmir-Turkey.

Koto R, Bani A, Topi T, Topi M, 2014. Water Quality and Heavy Metal Content of Karavasta Lagoon in Albania. Fresenius Environmental Bulletin, 23 (12b): 3296-3302.

Mahaffey C, Palmer M, Greenwood N, Sharples J, 2020. Impacts of Climate Change on Dissolved Oxygen Concentration Relevant to the Coastal and Marine Environment around the UK. Marine Climate Change Impacts Partnership Science Review 2020, 31-53.

Ölmez M, Saraç D, 2009. Su Ürünleri İçin Ph’nın Önemi. Ziraat Mühendisliği Dergisi, 353: 12-17.

Özdemir N, Alparslan E, 2013. Güllük Lagünü'nün su kalitesi yönünden incelenmesi. Bacteriology of Güllük Bay TÜBİTAK Project Workshop, Mugla, May 10, 2013, pp: 53-67.

Storie J, Suškevičs M, Külvik M, Lehtoranta V, Vikström S, Riikonen S, Kuosa H, Kuhn K, Oinonen S, 2020. What Evidence Exists For The İmpact Of Baltic Sea Ecosystems On Human Health And Well-Being? A Systematic Map Protocol. Environmental Evidence, 9 (5): 1-9.

Topi T, Bani A, Sulce S, 2013. Physico Chemical Characteristics and Heavy Metal Contents of Water from Butrinti Lagoon, Albania. Albanian Journal of Agricultural Sciences, 12 (2): 321.

Turkey Recreational Standards, 2006, State of Turkey, Annexes 1, 1.

U.S. EPA, 1986. Standard for human health and for aquatic life, in Quality criteria for water ("Gold Book"), Appendix A, 233.

Vouvé F, Buscail R, Aubert D, Labadie P, Chevreuil M, Canal C, Desmousseaux M, Alliot F, Amilhat E, Faliex E, Paris-Palacios S, Biagianti-Risbourg S, 2014. Bages-Sigean and Canet-St Nazaire Lagoons (France): Physico-Chemical Characteristics and Contaminant Concentrations $(\mathrm{Cu}, \mathrm{Cd}$, PCBs and PBDEs) as Environmental Quality of Water and Sediment. Environmental Science and Pollution Research, 21 (4): 3005-3020.

Yuan Y, Sun T, Wang H, Liu Y, Pan Y, Xie Y, Huang H, Fan Z, 2020. Bioaccumulation and Health Risk Assessment of Heavy Metals to Bivalve Species in Daya Bay (South China Sea): Consumption Advisory. Marine Pollution Bulletin, 150: 110717. 